\title{
Landmark Papers on Blood and Component Transfusion Therapy in the Critically Ill: A Critical Analysis
}

\author{
Ruchira Wasudeo Khasne ${ }^{1}$, Pradnya Atul Kulkarni ${ }^{2}$, Atul P Kulkarni ${ }^{3}$ \\ Keywords: Acute coagulopathy of trauma, Blood transfusion, Coagulopathy, Fresh frozen plasma, Packed red blood cell \\ Indian Journal of Critical Care Medicine (2019): 10.5005/jp-journals-10071-23254
}

Transfusion of blood and its components is one of the most common interventions in the ICU. The current literature in transfusion therapy revolves around three main areas:

1. Restrictive vs. liberal transfusion strategy.

2. The storage time of blood and its effects.

3. The use of component therapy and the ratios of components transfused and patient outcomes.

We have grouped the studies in each area, and give our comments about their relevance to the clinicians.

\section{Restrictive Strategy vs Liberal Strategy of Red-cell Transfusion}

The TRICC trial ${ }^{1}$ is a truly landmark trial, as it defined the restrictive red blood cell transfusion as the new NORMAL in the critically ill. In this trial, in the restristive strategy group, the in-hospital mortality ( $22.2 \%$ vs. $28.1 \%, P=0.05$ ), and mortality in younger (age $<55$ years, $5.7 \%$ vs. $13.0 \%, P=0.02$ ), less sick (APACHE II $<20,8.7 \%$ vs. $16.1 \%$ $\mathrm{P}=0.03$ ) was significantly lower but not in those with significant cardiac disease. However the CONSORT diagram showed a lot of exclusions, some unusual in nature, drawing some criticism whether the trial could be genuinely applicable to all comers in the ICU (838 included out of 6451 screened). On subgroup analysis, no significant differences in 30-day mortality were seen with restrictive strategy in patients with cardiac disease $(20.5 \%$ vs $22.9 \% ; P=0.69)$, severe infections and septic shock ( $22.8 \%$ vs $29.7 \% ; P=0.36$ ), or trauma (10.0\% vs $8.8 \% ; P=0.81)$. It left questions regarding role of restrictive transfusion strategy in patients with significant cardiac disease and septic shock unanswered.

The TRISS trial ${ }^{2}$, another landmark trial in the continuum of restrictive strategy, signaled an end to the old tradition of generous red cell transfusion in patients with septic shock. This trial included patients with septic shock (as per the old definition ${ }^{3}$ ), except those who also had acute coronary syndrome, ongoing bleeding, limitation of therapy, and others. There were no differences in primary outcome (90-day mortality, $43.0 \%$ in the lower- threshold group vs $45.0 \%$; RR, $0.94 ; 95 \% \mathrm{Cl}, 0.78$ to $1.09 ; \mathrm{P}=0.44$ ), and use of life support therapy (secondary outcome) at days 5, 14 and 28 days. The mortality was also similar in older patients i.e. $>70$ years $(0.98,95 \% \mathrm{Cl} 0.79-1.18)$ those with chronic cardiovascular disease $(1.08,95 \% \mathrm{Cl} ; 0.75-1.40)$, and sicker patients (SAPS > 53, 0.83, 95\% $\mathrm{Cl} ; 0.64-1.04)$. The trial had a low risk of bias and the trial design was quite pragmatic. Since there were minimal exclusions, it can be widely and routinely applied in our routine practice. By the authors own admission, due to the wide confidence intervals observed in the primary outcome, a $9 \%$ relative increase or a $22 \%$ relative decrease the lower-threshold group compared to the higher-
${ }^{1}$ Department of Critical Care, Ashoka Medicover Hospital, Nashik, Maharashtra, India

${ }^{2}$ Blood Bank, Department of Pathology, KJ Somaiya Hospital, Mumbai, Maharashtra, India

${ }^{3}$ Division of Critical Care Medicine, Department of Anesthesiology, Critical Care and Pain, Tata Memorial Hospital, Homi Bhabha National Institute, Mumbai, Maharashtra, India

Corresponding Author: Atul P Kulkarni, Division of Critical Care Medicine, Department of Anesthesiology, Critical Care and Pain, Tata Memorial Hospital, Homi Bhabha National Institute, Mumbai, Maharashtra, India, e-mail: kaivalyaak@yahoo.co.in

How to cite this article: Khasne RW, Kulkarni PA, Kulkarni AP. Landmark Papers on Blood and Component Transfusion Therapy in the Critically III: A Critical Analysis. Indian J Crit Care Med 2019;23(Suppl 3):S207-S211. Source of support: Nil

Conflict of interest: None

threshold group, cannot be ruled out. However, overall, it was a well conducted, practice changing trial. Further information regarding role of restrictive strategy in patients with septic shock may be available soon from the study proposed by Jonsson $A B$, et al. ${ }^{4}$

The trial by Gobatto ALN, et al., ${ }^{5}$ deserves a separate mention, as it goes against the grain of the restrictive strategy in general. However, the hypothesis that reduced oxygen supply to the brain during acute phase of insult (due to restrictive strategy) may compromise the long-term outcomes is tenable. We may adopt this approach in-spite of several limitations noted by the authors in the article (small sample size, single center trial, slow recruitment, lack of ICP measurements) till we get conclusive evidence from further research.

There are other trials addressing the question of restrictive transfusion in various subgroups, mainly in the patients with cardiovascular surgery and disease, brain trauma and upper Gl bleeding. Except for patients with brain trauma (see above), where liberal transfusion may be better, restrictive strategy appears to be useful (Table 1).

\section{Storage Time of Blood and Outcomes}

Red cell storage lesions affect not only the red cells but also red cells collected for transfusion and preserved in solutions. Since S-nitrosothiol-Hb (SNO-Hb) is immediately degraded following blood collection, it compromises the capacity the RBCs to enhance the production of nitric oxide (NO), which reduces the vasodilatory ability of RBCs. Other changes comprise of reduced levels of 2,3-Diphosphoglycerate (2,3-DPG), paralysis of sodium- potassium

(0) The Author(s). 2019 Open Access This article is distributed under the terms of the Creative Commons Attribution 4.0 International License (https://creativecommons. org/licenses/by-nc/4.0/), which permits unrestricted use, distribution, and non-commercial reproduction in any medium, provided you give appropriate credit to the original author(s) and the source, provide a link to the Creative Commons license, and indicate if changes were made. The Creative Commons Public Domain Dedication waiver (http://creativecommons.org/publicdomain/zero/1.0/) applies to the data made available in this article, unless otherwise stated. 
Table 1: Restrictive strategy vs liberal strategy of red-cell transfusion

\begin{tabular}{llll}
\hline Study & Participants, groups & Type of study & Result \\
\hline $\begin{array}{l}\text { Gobatto et al. (Crit Care. } \\
2019)^{5}\end{array}$ & $\begin{array}{l}\mathrm{N}=44, \text { Head injured } \\
\text { patients (Liberal group: } 21, \\
\text { Restrictive group: 23) }\end{array}$ & $\begin{array}{l}\text { Randomized controlled } \\
\text { feasibility trial }\end{array}$ & $\begin{array}{l}\text { There was negative correlation }(r=-0.265, p<0.01) \\
\text { between hemoglobin concentration and MCA flow } \\
\text { velocity, and the incidence of post-traumatic vasospasm } \\
\text { was significantly lower in the liberal strategy group }\end{array}$ \\
& & & $(4 / 21,3 \%$ vs $15 / 23,65 \% ; p<0.01)$. Hospital mortality was \\
& & & higher in the restrictive than in the liberal group $(7 / 23$ vs \\
& & $1 / 21 ; p=0.048)$ and the liberal group tended to have a \\
& & better neurological status at 6 months $(p=0.06)$.
\end{tabular}

Hébert PC et al. (CCM $2001)^{6}$

Hajjar LA et al. TRACS Trial $\left(\right.$ JAMA 2010) ${ }^{7}$

Villanueva $C$ et al. Acute UGI bleed (NEJM 2013) ${ }^{8}$
Pts with CVS disease $\mathrm{N}=357$ (Restrictive 160, Liberal group 197)

$\mathrm{N}=253$ pts vs. 249 pts. 198 of 253 (liberal group) 118 of 249 (restrictive group) received transfusions. $\mathrm{N}=889$, Restrictive group 444, Liberal group 445.
Prospective randomized controlled trial

Prospective randomized Trial

Similar mortality rates, including 30 -day ( $23 \%$ vs $23 \%$; $p=1.00), 60$-day, hospital, and ICU mortality. Changes in MODS from baseline were significantly less in the restrictive group $(0.2 \pm 4.2$ vs $1.3 \pm 4.4 ; p=.02)$.

The number of transfused red blood cell units was an independent risk factor for clinical complications or death at 30 days (HR for each additional unit, $1.2[95 \% \mathrm{Cl}$, 1.1-1.4]; $P=0.002$ ).

Prospective Randomized The survival probability at 6 weeks was higher in the controlled clinical trial
Mazer et al. TRIC III, (NEJM 2017) ${ }^{9}$
$\mathrm{N}=5243$, Cardiac surgery patients 2430 Restrictive, 2430 Liberal group
Multicenter, open-label, noninferiority trial restrictive- group ( $95 \%$ vs. $91 \%$; HR, $0.55 ; 95 \%$ [Cl], 0.33 to $0.92 ; \mathrm{P}=0.02)$. Further bleeding occurred in lower no of patients $(10 \%$ vs. $16 \mathrm{P}=0.01)$, as well as lower no. adverse events in $(40 \%$ vs. $48 \%(P=0.02)$ in restrictive group. The probability of survival was significantly higher in the subgroup of patients with cirrhosis and Child-Pugh class A or $B$ disease (HR, $0.30 ; 95 \% \mathrm{Cl}, 0.11$ to 0.85 ), but not in those with cirrhosis and Child-Pugh class $C$ disease (hazard ratio, 1.04; 95\% Cl, 0.45 to 2.37).

A restrictive strategy regarding red-cell transfusion was noninferior to a liberal strategy with respect to the composite outcome of death from any cause, myocardial infarction, stroke, or new-onset renal failure with dialysis, with less blood transfused. pump (leading to leakage of intracellular $\mathrm{K}^{+}$) and most importantly the ability to deform, to reach the microcirculation. ${ }^{10}$

This led to the hypothesis that the transfusion of old blood may affect the efficacy of RBCs and outcomes of the patients given old blood. Walsh et al. ${ }^{11}$ comparing transfusion of old vs. fresh $(5 \mathrm{~d}$ vs. $2 \mathrm{~d}$ ) blood failed to show any difference in $\mathrm{Pg}-\mathrm{PaCO}_{2}$ gap, gastric $\mathrm{pHi}$, arterial $\mathrm{pH}, \mathrm{BE}$ and lactate. The $\mathrm{DPaO}_{2} / \mathrm{FiO}_{2}$ were also found to be similar (fresh $5 \mathrm{~d}$ vs. $26 \mathrm{~d}$ old) in another study. ${ }^{12}$

No differences were reported by Herbert et al. ${ }^{13}$ when comparing clinical outcomes (death or a life-threatening complication) in a pilot trial. Koch's et al. ${ }^{14}$ conducted a large retrospective trial (6002 patients) comparing transfusion with old vs fresh blood (11 vs $20 \mathrm{~d}$ ). Patients given older units had higher in-hospital mortality ( $2.8 \%$ vs $1.7 \%, P=0.004)$, needed prolonged intubation $>72 \mathrm{~h}(9.7 \%$ vs $5.6 \%, P<0.001)$, had higher incidence of renal failure $(2.7 \%$ vs $1.6 \%, P=0.003)$, and sepsis ( $4.0 \%$ vs $2.8 \%$, $P=0.01)$. The beneficial effect on mortality was seen up to one year (7.4\% vs $11.0 \%, P<0.001$ ) (Table 2 ).

The ABLE study ${ }^{15}$ (Age of Transfused Blood in Critically III Adults) was a prospective, double-blind, multicenter randomized controlled trial, which included 2430 patients. The median length of storage of transfused blood was $6.1 \pm 4.9 \mathrm{~d}$ (vs $22.0 \pm 8.4 \mathrm{~d}, p<0.001$ ) in the fresh arm. The groups were similar at baseline. The 90 -day all-cause mortality after randomization was $448(37.0 \%)$ in the fresh arm and 430 (35.3\%) in the control arm (ARR: 1.7\%; 95\% confidence interval: $-2.1 \%$ to $5.5 \%)$. The risk of death was higher in the fresh arm (HR: 1.1; $95 \% \mathrm{Cl}: 0.9$ to $1.2, \mathrm{p}=0.38$ ). Except for development of ARDS and use of vasoactive drugs, all other organ support requirements, development of secondary complications and the MODS, tended to be better in patients who received older blood. It is possible that a smaller number of critically ill patients, likely to be affected adversely by transfusion of old blood (such as elderly patients, patents with trauma and higher volumes of transfusion), were included. The authors suggest that shorter storage time (i.e. fresher blood) may have resulted in different outcomes, but that is not really pragmatic, since testing for infectious diseases takes at least 72 hours. The authors concluded that they could not find any clinically important benefits of transfusion of fresh blood.

The TRANSFUSE (Standard Issue Transfusion versus Fresher RedCell Use in Intensive Care) trial, ${ }^{16}$ prospectively randomized nearly 5000 critically ill patients to either receive fresh (11 d) or old blood. The 90 -day [24.8\% vs. 594, ARR, $0.7 ; 95 \%$ [Cl], -1.7 to $3.1 ; \mathrm{p}=0.57]$ and 180 -day mortality ( $28.5 \%$ vs. $28.1 \%$, ARR 0.4 percentage points; $95 \%$ $\mathrm{Cl},-2.1$ to $3.0 ; \mathrm{P}=0.75$ ) was similar in patients who received fresh as compared older blood. The secondary outcomes, 28-day mortality; the rates of persistent organ dysfunction or death at day 28 , febrile nonhemolytic transfusion reactions, mechanical ventilation, and renal-replacement therapy; or ICU length of stay were also similar in the two groups. The limitations of this trial were not specifying the age of blood cells and not specifying that the blood cells nearing their expiry not to be transfused. However, it is unlikely that this would have affected the outcomes. The authors concluded that 
Landmark Papers on Blood and Component Transfusion Therapy in the Critically Ill: A Critical Analysis

Table 2: Storage time of blood and outcomes

\begin{tabular}{|c|c|c|c|}
\hline Study & Participants, groups & Type of study & Results \\
\hline $\begin{array}{l}\text { - Yamal JM et al (J Trauma } \\
\text { Acute Care Surg. 2015) } \\
\text { - } \text { RBC age and } \\
\text { oxygenation, } \\
\text { Neurological outcome, } \\
\text { mortality in TBI. }{ }^{17}\end{array}$ & $\begin{array}{l}\mathrm{N}=125, \text { Mean RBC age } \\
>21 \mathrm{~d} 68 \text { patients, Mean } \\
\text { RBC age }<21 \mathrm{~d} \\
57 \text { patients }\end{array}$ & $\begin{array}{l}\text { Retrospective analysis of } \\
\text { data from a trial (JAMA. } \\
2014 ; 312: 36-47){ }^{17} \\
2 \times 2 \text { factorial } \\
\text { randomized controlled } \\
\text { trial }\end{array}$ & $\begin{array}{l}\text { No association of } \mathrm{RBC} \text { age with } \mathrm{SjvO}_{2} \text { (jugular venous } \\
\text { oxygen saturation) (linear regression } \beta=1.59 ; 95 \% \mathrm{Cl} \\
=-2.99-6.18 ; p=0.49 \text { ), brain tissue oxygenation (linear } \\
\text { regression } \beta=0.20 ; 95 \% \mathrm{Cl}=-0.23-0.63 ; p=0.36 \text { ), } \mathrm{GOS} \\
\text { score (odds ratio }=1.37 ; 95 \% \mathrm{Cl}=0.53-3.57 ; p=0.52 \text { ), } \\
\text { and mortality (hazard ratio }=1.35 ; 95 \% \mathrm{Cl}=0.61-2.98 \\
p=0.46 \text { ). }\end{array}$ \\
\hline $\begin{array}{l}\text { Steiner ME et al. (N Engl } \\
\text { J Med. 2015) complex } \\
\text { cardiac surgery. }{ }^{19}\end{array}$ & $\begin{array}{l}\mathrm{N}=1098 \\
\text { Red cell storage } \leq 10 \mathrm{~d} \\
=538 \text { patients, Red cell } \\
\text { storage } \geq 21 \text { days }=560 \\
\text { patients }\end{array}$ & Randomized control trail & $\begin{array}{l}\text { The median storage time } 7 \mathrm{~d} \text { vs } 28 \mathrm{~d} \text { The mean change in } \\
\text { MODS was an increase of } 8.5 \text { and } 8.7 \text { points, respectively } \\
(95 \% \mathrm{Cl},-0.6 \text { to } 0.3 ; P=0.44) \text {. The } 7 \text {-day mortality was } \\
2.8 \% \text { vs. } 2.0 \%(p=0.43) \text { in the shorter-term storage group. } \\
28 \text {-day mortality was } 4.4 \% \text { and } 5.3 \% \text {, respectively ( } P= \\
0.57 \text { ). Hyperbilirubinemia more common in the longer- } \\
\text { term storage group, no other effects. }\end{array}$ \\
\hline $\begin{array}{l}\text { Heddle NM et al. (N Engl J } \\
\text { Med. 2016) }\end{array}$ & $\begin{array}{l}\mathrm{N}=20,858 \text { patients (with } \\
\text { A or O group) short-term } \\
\text { storage: } 6936 \text { patients; } \\
\text { long-term storage: } \\
\text { 13,922 patients }\end{array}$ & $\begin{array}{l}\text { Randomized controlled } \\
\text { trial }\end{array}$ & $\begin{array}{l}\text { The mean storage duration was } 13.0 \text { vs } 23.6 \text { days. There } \\
\text { were more deaths in short-term storage group [ } 634 \\
\text { deaths }(9.1 \%) \text { vs } 1213(8.7 \%), O R, 1.05 ; 95 \% \mathrm{Cl}, 0.95 \text { to } \\
1.16 ; p=0.34] \text {. Additional results were consistent in } \\
\text { three prespecified high-risk subgroups (pts undergoing } \\
\text { cardiovascular surgery, admitted to ICU, and those with } \\
\text { cancer). }\end{array}$ \\
\hline
\end{tabular}

we should continue the current practice of transfusing the oldest blood available in the blood bank (First in-first out).

In our daily practice in India, we must keep 2 facts in mind, while applying the results of these trials in particular and blood transfusion trials in general, in toto. The blood that is available in most advanced countries is universally leukodepleted before transfusion. The process of leukodepletion is costly and we generally do not use leukodepleted blood except in specific circumstances such as in patients undergoing transplants (this blood also undergoes gamma irradiation). Apart from causing RBC storage lesions, the residual leukocytes and platelets influence the contents of stored blood. Leukocyte deletion leads to reduced potassium leakage and hemolysis. Nonleukocyte-depleted RBCs have procoagulant effects and increased adherence potential to endothelium. ${ }^{10}$ We do not know fully how these factors would have affected the outcomes of the trials described above. Another confounding factor in these trials is a lack of definition of what is fresh and what is old blood. Since various trials have defined these differently, this also hampers interpretation of the results.

\section{Component Therapy and Outcomes}

Acute traumatic coagulopathy is a common occurrence. The putative causative mechanisms include exposure hypothermia, hemodilution due to intravenous fluid therapy, massive blood transfusion, and acidosis. Brohi et al $^{21}$ examined data from over 1600 patients retrospectively and concluded that acute coagulopathy of trauma is a marker of injury severity and was directly related to mortality. Mediators released after trauma activate the coagulation, fibrinolysis, complement, and kallikrein systems. These affect the hemostatic mechanisms and lead to development of SIRS and MODS. Sperry et al., ${ }^{22}$ analyzed data of 415 patients from the "Inflammation and the host response to injury, a large-scale collaborative project" ${ }^{\prime 23}$ who required $>8$ packed red blood cells (PRBCs) in first 12 hours. They hypothesized that the immediate mortality of patients with blunt trauma will be reduced when given FFP in a higher ratio, but the survivors will have a higher rate of complications (such as MODS and nosocomial infections) due to the infusion of FFPs. They found a significant reduction in the $24 \mathrm{~h}$ mortality (high F:P ratio $3.9 \%$ vs. low $12.8 \%, p=0.012$ ) but overall mortality was similar in 2 groups. Infusion of high F:P ratio in first 12 h was associated with lower mortality (adjusted HR 0.48, $p=0.002$, $95 \% \mathrm{Cl} 0.3-0.8)$. However the incidence of nosocomial infections and ARDS was significantly higher in the high ratio group. Another study compared feasibility of achieving high fixed ratio transfusion (1:1:1) with lab-guided resuscitation. ${ }^{24}$ They concluded that high ratio infusion was possible but resulted in significant wastage of FFPs. The mortality and complications were similar in both the groups. The Prospective, Observational, Multicenter, Major Trauma Transfusion (PROMMTT) Study, found that the transfusion practices of Plasma: RBC and Platelet: RBC ratios in $24 \mathrm{~h}$ were varied. ${ }^{25} \mathrm{Higher}$ Plasma: RBC (adjusted $\mathrm{HR}=0.31 ; 95 \% \mathrm{Cl}, 0.16-0.58$ ) and Platelet: $\mathrm{RBC}$ ratios (adjusted $\mathrm{HR}=0.55 ; 95 \% \mathrm{Cl}, 0.31-0.98$ ) led to a significant reduction in $6 \mathrm{~h}$ mortality (Table 3 ).

The truly landmark trial in this area was the PROPPR study. ${ }^{26}$ This was a prospective, pragmatic, multicenter, randomized trial. It included 680 patients requiring highest trauma level activation and predicted to require massive transfusions (by predefined criteria), who were randomized to receive blood products either in the ratio of 1:1:1 (338) or 1:1:2 (342). The treating physicians were blinded to the patient assignments till they opened the pre-packed containers of blood products, delivered to the ED within $10 \mathrm{~min}$. The sequence of transfusion of all products was predetermined in the study protocol. Transfusion of blood products was stopped when clinically indicated. The primary outcome was $24 \mathrm{~h}$ and 30 day mortality. Data of 23 other complications was also collected. The clinicians assessing the outcomes were blinded to the group assignments and assgined one or more cause of death. There were no significant differences in mortality at $24 \mathrm{~h}$ or at 30 days. Death due to exsanguination was reduced $(9.2 \%$ vs. $14.6 \%$ in $1: 1: 1$ group; difference, $-5.4 \%$ [95\% Cl, $-10.4 \%$ to $-0.5 \%] ; P=0.03$ ) in patients who received transfusion at higher ratio since higher number of patients achieved hemostasis in this group ( $86 \%$ vs. $78 \%, P=0.006)$. 
Table 3: Component therapy and outcomes

\begin{tabular}{|c|c|c|c|}
\hline Study & Participants, groups & Type of study & Results \\
\hline $\begin{array}{l}\text { Sperry JL, et al. (J } \\
\text { Trauma. 2008) }\end{array}$ & $\begin{array}{l}\mathrm{N}=415 \\
\text { Patients who required }>8 \\
\mathrm{u} P R B C s<12 \text { hours post- } \\
\text { injury } \\
>1: 15: \text { F: } P \text { ratio: } 102 \\
<1: 15: \text { F: } P \text { ratio: } 313\end{array}$ & $\begin{array}{l}\text { Data from } \\
\text { Maier RV, et al. (J } \\
\text { Trauma. 2005) }\end{array}$ & $\begin{array}{l}\text { Patients with high ratio transfusion products required } \\
\text { significantly less blood transfusion at } 24 \text { hours ( } 16+/-9 \text { units vs } \\
22+/-17 \text { units, } p=0.001 \text { ). Crude mortality differences between } \\
\text { the groups did not reach statistical significance (high F:P } 28 \% \\
\text { vs low F: P } 35 \%, p=0.202) \text {. Significant difference in early ( } 24 \\
\text { hour) mortality (high F:P } 3.9 \% \text { vs low F:P } 12.8 \%, p=0.012 \text { ). Cox } \\
\text { proportional hazard regression revealed that receiving a high } \\
\text { F:P ratio was independently associated with } 52 \% \text { lower risk of } \\
\text { mortality after adjusting for important confounders (HR } 0.48 \text {, } \\
p=0.002,95 \% \mathrm{Cl} 0.3-0.8 \text { ). }\end{array}$ \\
\hline
\end{tabular}

Nascimento $\mathrm{B}$, et al. $\mathrm{N}=78$

(CMAJ 2013; 185: Patients with hemorrhage, $\mathrm{E} 583-9)^{24}$

\section{hypotension}

48 patients Fixed ratio (1:1:1) vs 38 patients Lab guided transfusion

Holcomb JB, et $\mathrm{N}=1245$ al. (JAMA Surgery $2013)^{25}$ Timing of transfusions during active resuscitation PROMMTT study
Prospective randomized Ratio of 1:1:1 was achieved in 57\% (21/37) of patients in the controlled feasibility trial fixed-ratio group, as compared with $6 \%(2 / 32)$ in the control group. A ratio of 1:1 (RBC: FP) was achieved in $73 \%$ (27/37) in the fixed-ratio group and $22 \%(7 / 32)$ in the control group. Plasma wastage was higher with the intervention protocol (22\% [86/390] of FP units v. 10\% [30/289] in the control group).
Prospective, observational, multicenter, major trauma transfusion study the first 24 hours $(P<0.001$ for both). In a multivariable time-dependent Cox model, increased ratios of plasma: RBCs (adjusted hazard ratio $=0.31 ; 95 \% \mathrm{Cl}, 0.16-0.58$ ) and platelets: $\mathrm{RBCs}$ (adjusted hazard ratio $=0.55 ; 95 \% \mathrm{Cl}, 0.31-0.98$ ) were independently associated with decreased 6-hour mortality, when hemorrhagic death predominated. In the first 6 hours, patients with ratios less than 1:2 were 3-4 times more likely to die than patients with ratios of 1:1 or higher. After 24 hours, plasma and platelet ratios were unassociated with mortality, when competing risks from nonhemorrhagic causes prevailed.
The rates of all 23 complications such as sepsis, MOF, ARDS and venous thromboembolism were similar in both groups.

This was a very well conducted trial with high levels of protocol adherence with appropriate separation of blood product ratios maintained throughout the study period. It was also blinded, had sufficiently large nos. (as per the adaptive design where the sample size was increased from 580 to 680 and nearly $100 \%$ patients accounted for at the end of follow up period (only $4 / 680$ lost to follow-up). The limitations include problems in the sample size due to differences in the projected and observed mortality in the lower ratio group (1:1:2) group, in that regard, this trial then becomes underpowered to detect the differences in mortality. Another limitation is inclusion of some patients with severe head injury due to need for rapid enrollment, who would have been otherwise excluded, due to high expected likelihood of mortality. These patients then added to the increased mortality in both groups.

Thus, in-spite of this trial being a negative trial with regards to the primary outcome (similar 24 h, $30 \mathrm{~d}$ mortality), it showed that transfusion of blood products in high ratio (1:1:1) reduces deaths due to exsanguination since a higher number of patients achieved hemostasis. We should aim to use higher ratios of blood products for initial resuscitation in severly injured patients who are expected to need massive transfusion.

\section{References}

1. Hébert PC, Wells G, Blajchman MA, Marshall J, Martin C, Pagliarello G, et al. A multicenter, randomized, controlled clinical trial of transfusion requirements in critical care. Transfusion Requirements in Critical Care Investigators, Canadian Critical Care Trials Group. N Engl J Med. 1999; 340:409-417.

2. Holst LB, Haase N, Wetterslev J, Wernerman J, Guttormsen AB, Karlsson S, et al, for TRISS Trial Group; Scandinavian Critical Care Trials
Group. Lower versus higher hemoglobin threshold for transfusion in septic shock. N Engl J Med. 2014;371:1381-1391.

3. American College of Chest Physicians/ Society of Critical Care Medicine Consensus Conference: definitions for sepsis and organ failure and guidelines for the use of innovative therapies in sepsis. Crit Care Med 1992;20:864-874.

4. Jonsson AB, Granholm A, Rygård SL, Holst LB, Møller MH, Perner A. Lower vs. higher transfusion threshold in septic shock patients of different ages: A study protocol. Acta Anaesthesiol Scand. 2019;63:1247-1250.

5. Gobatto ALN, Link MA, Solla DJ, Bassi E, Tierno PF, Paiva W, et al. Transfusion requirements after head trauma: a randomized feasibility controlled trial. Crit Care 2019;23:89.

6. Hébert PC, Yetisir E, Martin C, for Transfusion Requirements in Critical Care Investigators for the Canadian Critical Care Trials Group. Is a low transfusion threshold safe in critically ill patients with cardiovascular diseases? Crit Care Med. 2001;29:227-234.

7. Hajjar LA, Vincent JL, Galas FR, Nakamura RE, Silva CM, Santos MH, et al. Transfusion requirements after cardiac surgery: the TRACS randomized controlled trial. JAMA 2010;304:1559-1567.

8. Villanueva C, Colomo A, Bosch A, Concepción M, Hernandez-Gea V, Aracil C, et al. Transfusion strategies for acute upper gastrointestinal bleeding. N Engl J Med. 2013;368:11-21.

9. Mazer CD, Whitlock RP, Fergusson DA, Hall J, Belley-Cote E, Connolly $\mathrm{K}$, et al., on behalf of the TRICS Investigators and Perioperative Anesthesia Clinical Trials Group. Restrictive or Liberal Red-Cell Transfusion for Cardiac Surgery. N Engl J Med 2017;377:2133-2144.

10. van de Watering $L M, B$ rand A. Effects of storage of red cells. Transfus Med Hemother. 2008;35:359-367.

11. Walsh TS, McArdle F, McLellan SA, Maciver C, Maginnis M, Prescott RJ, et al. Does the storage time of transfused red blood cells influence regional or global indexes of tissue oxygenation in anemic critically ill patients? Crit Care Med. 2004;32:364-371

12. Kor DJ, Kashyap R, Weiskopf RB, Wilson GA, van Buskirk CM, Winters $\mathrm{JL}$, et al. Fresh red blood cell transfusion and short-term pulmonary, 
immunologic, and coagulation status: a randomized clinical trial. Am J Respir Crit Care Med. 2012;185:842-850.

13. Hébert PC, Chin-Yee I, Fergusson D, Blajchman M, Martineau R, Clinch $\mathrm{J}$, et al. A pilot trial evaluating the clinical effects of prolonged storage of red cells. Anesth Analg. 2005;100:1433-8.

14. Koch CG, Li L, Sessler DI, Hoeltge GA, Mihaljevic T, Blackstone EH. Duration of red-cell storage and complications after cardiac surgery. N Engl J Med. 2008;358:1229-1239.

15. Lacroix J, Hébert PC, Fergusson D, Tinmouth A, Capellier G, Tiberghien P, et al for Canadian Critical Care Trials Group. The ABLE study: A randomized controlled trial on the efficacy of fresh red cell units to improve the outcome of transfused critically ill adults. Transfus Clin Biol. 2015;22:107-111.

16. Cooper DJ, McQuilten ZK, Nichol A, Ady B, Aubron C, Bailey M, et al. TRANSFUSE Investigators and the Australian and New Zealand Intensive Care Society Clinical Trials Group. Age of red cells for transfusion and outcomes in critically ill adults. N Engl J Med 2017;377:1858-1867.

17. Robertson CS, Hannay HJ, Yamal JM, Gopinath S, Goodman JC Tilley BC; et al. Effect of erythropoietin and transfusion threshold on neurological recovery after traumatic brain injury: a randomized clinical trial. JAMA. 2014;312:36-47.

18. Yamal JM, Benoit JS, Doshi P, Rubin ML, Tilley BC, Hannay HJ, et al. Association of transfusion red blood cell storage age and blood oxygenation, long-term neurologic outcome, and mortality in traumatic brain injury. J Trauma Acute Care Surg. 2015;79:843-9.

19. Steiner ME, Ness PM, Assmann SF, Triulzi DJ, Sloan SR, Delaney M, et al. Effects of red-cell storage duration on patients undergoing cardiac surgery. N Engl J Med. 2015;372:1419-1429.
20. Heddle NM, Cook RJ, Arnold DM, Liu Y, Barty R, Crowther MA, et al. Effect of Short-Term vs. Long-Term Blood Storage on Mortality after Transfusion. N Engl J Med. 2016;375:1937-1945.

21. Brohi K, Singh J, Heron M, Coats T. Acute traumatic coagulopathy. J Trauma. 2003;54:1127-1130.

22. Sperry JL, Ochoa JB, Gunn SR, Alarcon LH, Minei JP, et al; Inflammation the Host Response to Injury Investigators. An FFP: PRBC transfusion ratio $>/=1: 1.5$ is associated with a lower risk of mortality after massive transfusion. J Trauma. 2008;65:986-993.

23. Maier RV, Bankey P, McKinley B, Freeman, B., Harbrecht, B. G., Johnson, et al. Inflammation and the host response to injury, a large-scale collaborative project: patient-oriented research corestandard operating procedures for clinical care [foreward]. J Trauma. 2005;59:762-763.

24. Nascimento B, Callum J, Tien H, Rubenfeld G, Pinto R, Lin Y, Rizoli S. Effect of a fixed-ratio (1:1:1) transfusion protocol versus laboratoryresults-guided transfusion in patients with severe trauma: a randomized feasibility trial. CMAJ. 2013;185:E583-9.

25. Holcomb JB, del Junco DJ, Fox EE, Wade CE, Cohen MJ, Schreiber MA, et al; PROMMTT Study Group. The prospective, observational, multicenter, major trauma transfusion (PROMMTT) study: comparative effectiveness of a time-varying treatment with competing risks. JAMA Surg. 2013;148:127-136.

26. Holcomb JB, Tilley BC, Baraniuk S, Fox EE, Wade CE, Podbielski JM, et al for PROPPR Study Group. Transfusion of plasma, platelets, and red blood cells in a 1:1:1 vs a 1:1:2 ratio and mortality in patients with severe trauma: the PROPPR randomized clinical trial. JAMA 2015;313:471-482 